\title{
The Impact of Globalization on Teaching Profession: The Global Teacher ${ }^{*}$
}

\author{
Suzan Canll ${ }^{1}$, Hasan Demirtaş ${ }^{2}$ \\ ${ }^{1}$ Altınsehir Middle School, Adıyaman, Turkey \\ ${ }^{2}$ Inönü University, Faculty of Education, Department of Educational Sciences, Malatya, Turkey \\ Correspondence: Suzan Canll, Altınsehir Middle School, Adıyaman, Turkey.
}

Received: November 13, 2017

Accepted: December 13, 2017

Online Published: December 22, 2017

doi:10.11114/jets.v6i1.2792

URL: https://doi.org/10.11114/jets.v6i1.2792

\begin{abstract}
The main objective of the present study was to examine the impact of globalization on the teaching profession based on teacher views. Furthermore, the study aimed to make recommendations for the practitioners and the researchers based on the study findings. In the study, the qualitative phenomenology research method was used and the participants were determined with maximum variety sampling method. The study group included 40 teachers employed in schools located at Adiyaman province central district in Turkey. A semi-structured interview form was used to collect the data in the study. The first section of the interview form included questions on participant demographics (gender, department, seniority, employment school type and education). The second part of the interview form included 5 questions that aimed to determine the participants' views on the impact of globalization on teaching profession. Descriptive and content analysis were conducted to analyze the study data. Based on the descriptions of the teachers on the concept of global teacher, it could be defined as a global citizen and a universal teacher who has knowledge on the global changes and developments and improves herself or himself accordingly and possesses the qualifications and competencies required by globalization in the study. Study findings demonstrated that globalization has resulted in changes in certain existing roles of the teachers. In the study, it was determined that globalization had negative effects besides several positive effects on teachers' qualifications. Based on the study findings, it could be argued the amendments in the teacher education system in Turkey did not reflect an adequate response to the impacts of globalization. On the other hand, it was observed that globalization had mostly positive effects on the teacher training process, however it was determined that there were certain adverse effects as well as these positive effects.
\end{abstract}

Keywords: globalization, global education, global teacher, teaching profession

\section{Introduction}

Globalization, which is considered as an international, intercultural, economic, political, cultural and social integration (Al-Rodhan \& Stoudmann, 2006) and defined as the concentration of global intercommunal relations induced by modernism and where distant settlements were interrelated and local events are shaped by distant events (Giddens, 2000), is the prominent topic in meetings, scientific conferences in various fields and the media and its popularity is constantly rising (Talas, 2016: 12-13).

Although the concept of globalization was initially introduced in the 1960s, it achieved its fame during the 1980s (Robertson, 1999, cited by Karaman, 2010: 131). On the other hand, it is considered that globalization has started with the civilization efforts of human beings and it is said to date back to the history of humanity (Elçin, 2012: 6). Globalization that was initially considered with the global climate change, ozone layer depletion and environmental issues such as airborne toxins and waste (Trisler, 1993: 2) became a phenomenon that is stressed frequently in the fields of economics, politics, and sociology. Because, globalization is a historical consequence of the desire and attempt to restructure the world and it is not possible to grasp globalization independent of the social, cultural, economic, and intellectual processes, evident in this historical process. In essence, globalization is a phenomenon that was initiated by developed countries to impose their economic, social and philosophical superiority on developing countries (Erkizan, 2002: 66). Globalization refers to a world where the constraints of time and space based on geographic limitations are

\footnotetext{
${ }^{*}$ This study was presented as verbal presentation at the $26^{\text {th }}$ International Conference on Educational Sciences in Side/Antalya/Turkey on April 2017.
} 
reduced, changes in communications and technology and economic, cultural and political changes become connected and interdependent, triggering and sustaining each other (Maguire, 2010: 59).

It could be argued that globalization is constantly present and continues its development and interaction, even though its pace varies due to social changes or certain economic processes (Elçin, 2012: 1). One of the factors that changed the rate of globalization, which existed since the beginning of human history, is the rapid advances in information, communications and transportation technologies. Due to these advances, communications and interaction between individuals and even societies have improved (Karaman, 2010: 132), and the world has turned into a "single space". However, this does not mean "global unity", that is, "downsizing to a single space". This is the awareness and communication of individuals with different traits and lifestyles with each other (Balc1, 2006: 27-28).

There is an attempt to impose globalization as a mandatory, irresistible and inevitable process irrespective of political will and ideological struggle. International capital seeks to control and determine all economic resources by designing the manufacturing globally in different fields and punish those who do not comply with its rules. While it is considered that the age of ideologies is over, globalization itself becomes the "big narrative" and attempts to impose its sovereignty with different methods (Kozanoğlu, 2002: 54). Thus, the nation states, which need to integrate with the powerful countries, are exposed to the impact of economically, culturally and politically powerful states and become dependent, the national borders are ignored and the concepts such as national sovereignty and independence lose their meaning, imperialist objectives are legitimized with the excuse of globalization causing a dilemma between remaining in globalization and preserving national unity, distribution of wealth and poverty both increase, the concern that the rich countries will further weaken the poor become prominent, certain fields of business disappear, negatively affecting employment, and the number of individuals without access to education increases instead of diminishing. On the other hand, with globalization, the countries in different parts of the world share knowledge, technologies and applications in various fields to solve several problems, common human values (human rights, equality, justice, etc.) are created with new and common lifestyles, common educational policies lead to common perceptions and understanding and new business fields provide new employment opportunities for individuals (Balay, 2004). Thus, the inevitable process of globalization has both positive and negative impacts and consequences.

Today, the countries adopt policies based on the inevitability of globalization and for several countries, the basic condition of survival became the adaptation to globalization with all its positive and negative consequences (Gümüş, 2013: 325). It was stated that one of the factors that were effective in this adaptation process was education. For example, according to Maguire (2010: 58), in a highly competitive international marketplace, education plays an important role in maintaining and sustaining competitive advantage of each society. Based on this perspective, survival and effectiveness of societies under international competition could only be accomplished with effective education systems that allow the acquisition of qualifications and competencies required by globalization (Çalık \& Sezgin, 2005: 60). In several countries with this awareness, attempts were made to implement the necessary educational regulations that would enable them to respond to globalization. Several countries, especially those that are aware of the significant of international comparisons such as TIMSS and PISA, attempted reforms in educational organizations and achieved measurable levels of success (Maguire, 2010: 58). Thus, several countries researched the qualified and competent type of individual as required by globalization and these researches led to comprehensive changes in the structure and operations in contemporary schools and applied curricula (Özdemir, 2011: 92-93) and it became obvious that education systems should become open and should not remain a closed box and organize educational content accordingly. Thus, today's educational programs should be organized to train individuals so that they could acquire experiences in globalization that could be influenced by international and intercultural interactions. It should also assist the individual to understand that she or he is an inseparable part of the world in which she or he lives in (Güven, 1999).

In the context of global values, the need for knowledge of other cultures, intercultural communication skills and intercultural competence increases (Merryfield, 1994: 4) and the type of a powerful and independent individual, who researches, could use knowledge and solve problems, becomes prominent (Akçay, 2003). Furthermore, it was suggested to implement the models that are sensitive to the lives of the students with different cultures and different social backgrounds and that adopt the philosophy of lifelong learning and train collaborative individuals (Yurdabakan, 2002). This necessitated a change in the existing approach of training individuals and altered the roles of educational institutions. Thus, in this period called the global age, it was deemed necessary to include the global education approach in education programs to educate the students based on the experienced changes (Güven, 1999: 146).

By the end of the twentieth century, the cultural diversity of human needs and the adoption of global education after education transcended the national boundaries resulted in the consideration of the adoption of global education as a requirement (Merryfield, 1994). Global education develops the knowledge, skills and attitudes that are the basis for active participation and decision-making in a world characterized by cultural pluralism, interdependence, inequality, collaboration, conflict and increasing international economic competition (Mc Fadden, Merryfield \& Barron, 1997: 9; 
Merryfield, 1994: 4, 1995: 2). Global education aims to provide the students a perspective that emphasizes the interrelationships and interactions between global cultures and societies and significantly focuses on the training students in that direction and ensuring the international adaptation of the students. The main objetive of global education is to develop in students the qualifications and competencies necessary to sustain their existence in "a world with limited natural resources and characterized by ethnic differences, cultural pluralism and more independent behavior" (Guven, 1999: 154).

Along with the changes in the educational approaches and the emphasis on global education, the qualifications and roles that are required of teachers should have also changed. The said change in teacher profile necessitated further reforms in education of teachers. Due to this requirement, several reforms have been and are implemented in teacher training systems in several countries including Turkey. Turkish teacher education system has a history of 169 years starting with the first teacher school established in 1848 (Aydın, 1998: 275). In this 169-year period, several changes were introduced in the Turkish teacher education system, and the related institutions were assigned different titles such as Darulmuallimin, Teacher Schools, Village Institutions, Primary School Teacher Schools, Educational Institutions and Faculty of Education until today (Akdemir, 2013; Üstüner, 2004). On the other hand, in 1997 and 2007, faculties of education were restructured due to the fact that the current teacher training system was inadequate to fulfill the current requirements. The teaching professionals were reorganized as "teaching technicians" with the teacher training model adopted in 1997 (Üstüner, 2004). On the other hand, the teacher education programs adopted in 2007 aimed to "train teachers who solve problems and teach how to learn, instead of the technician teacher who obeys what she or he is told to do". New program included general culture, social service courses, and social service course aimed the students to prepare projects to determine current problems in the society and produce solutions and motivate the students to participate in conferences, symposiums, panels, etc. It was also proposed to open elective courses on "professional ethics" similar to those available in Europe and in the United States in teacher education programs (Higher Education Council [YÖK], 2007). Finally, YÖK President Prof. Dr. Yekta Saraç stated that as an input-based regulation for education faculties, the achievement ranking system would be introduced and also a process and output-based alteration would be implemented (YÖK, 2016). It could be argued that these changes were implemented due to several reasons, including particularly the globalization. In fact, it was claimed in the debate on educational reform by various parties that the thesis of globalization was effective in these changes (Maguire, 2010). The real objective of these changes implemented in the teacher training system was the approach to train active and successful teachers who could comply with current requirements.

\subsection{The Objective of the Study}

Several studies were conducted on globalization in Turkey. However, the impact of globalization on the teaching profession were partially included in studies that generally examined the effects of globalization on education (Aslan, 2004; Balay, 2004; Balkar \& Özgan, 2010; Bolat \& Çelik, 2014; Cantekin, 2015; Cerit, 2004, Çalık \& Sezgin, 2009; Dagli, 2007; Güven, 1999; İlhan, 2009; Karaman, 2010; Özdemir, 2011; Öz Kılınç, 2009; Şahin, 2004; Uslu Çetin, 2015). Furthermore, there are studies on a combination of issues such as international globalization, global education, teaching profession and teacher education (Apple, 2011; Bruce, Podemski \& Anderson, 1991; Mc Fadden et al., 1997; Merryfield, 1994; 1995; 1996; Reimer \& Mc Lean, 2009; Schwille, Dembélé \& Schubert, 2007; Tatto, 2006; Torney-Purta, 1982) and on global teaching (Easterly, 1994; Enanoza \& Abao, 2014; Pinnock \& Nicholls, 2012; Rathi \& Ramachandran, 2012; West, 2013). On the other hand, considering that globalization could affect each country differently, in-depth studies should be conducted in Turkey to better understand the effect of globalization on the teaching profession.

Since it became important to have qualified teachers with the emphasis on globalization, various reforms were implemented in teacher training system in Turkey similar to several other countries. Teachers, who are responsible for training productive individuals for the society, are the practitioners of educational policies and influence the outcomes of educational policies. Thus, the need for improvement in teacher education is a current issue, and teachers with global qualifications should be trained to raise the quality of education that faces global challenges (Tarman, 2010: 79). Thus, it is necessary to assess the changes implemented in Turkish teacher education system due to globalization, examine the effect of globalization on Turkish teacher education system and the qualifications and the roles teachers in the resulting global teacher profile. Based on the view that those who could feel and observe the effects of globalization on teaching profession in minute detail would be the practitioners, the main objective of the present study was to examine the impact of globalization on the teaching profession based on the views of teachers. Furthermore, the study aimed to make recommendations for the practitioners and the researchers based on the study findings. Thus, the following research questions were addressed in the current study:

1. What are the views of teachers on the concept of global teacher? 
2. What are the views of teachers on the changes that were implemented in Turkish teacher education system due to globalization?

3. What are the views of teachers on the impact of globalization on teacher training process?

4. What are the views of teachers on the impact of globalization on teacher roles?

5. What are the views of teachers on the impact of globalization on teacher qualifications?

\section{Methodology}

In the study, the qualitative phenomenology research method was used and the participants were determined with maximum variety sampling method. The maximum variety sampling method aims to increase the diversity of the individuals in the sample with respect to the topic of the research and to determine similar and different views of these diverse individuals on the topic (Yıldırım \& Şimşek, 2011). The study group included 40 teachers employed in schools located at Adiyaman province central district in Turkey. A semi-structured interview form was used to collect the data in the study. Participant demographics is presented in Table 1.

Table 1. Demographics of the teachers who participated in the study

\begin{tabular}{|c|c|c|c|c|c|}
\hline Code & Gender & Department & $\begin{array}{l}\text { Seniority } \\
\text { (years) }\end{array}$ & School Type & $\begin{array}{l}\text { Education } \\
\text { Level }\end{array}$ \\
\hline T1 & Male & Turkish Language & $1-10$ & Junior High & Undergraduate \\
\hline $\mathbf{T 2}$ & Female & Classroom Teacher & $11-20$ & Elementary & Graduate \\
\hline T3 & Female & Turkish Language and Literature & $11-20$ & High School & Undergraduate \\
\hline T4 & Female & English & $1-10$ & Junior High & Undergraduate \\
\hline T5 & Male & Information Technologies & $11-20$ & High School & Undergraduate \\
\hline T6 & Male & Religious Culture and Ethics & $11-20$ & High School & Undergraduate \\
\hline T7 & Male & German & $21 \&$ over & High School & Undergraduate \\
\hline T8 & Male & Chemistry & $11-20$ & High School & Graduate \\
\hline T9 & Female & Classroom Teacher & $11-20$ & Elementary & Undergraduate \\
\hline T10 & Male & Mathematics & $21 \&$ over & High School & Undergraduate \\
\hline T11 & Male & Fen ve Teknoloji & $11-20$ & Junior High & Undergraduate \\
\hline T12 & Male & Biyoloji & $11-20$ & High School & Graduate \\
\hline T13 & Male & Turkish Language and Literature & $11-20$ & High School & Undergraduate \\
\hline T14 & Male & Turkish Language and Literature & $11-20$ & High School & Undergraduate \\
\hline T15 & Male & Turkish Language and Literature & $11-20$ & High School & Graduate \\
\hline T16 & Male & Fizik & $11-20$ & High School & Undergraduate \\
\hline T17 & Female & Görsel Sanatlar & $21 \&$ over & High School & Undergraduate \\
\hline T18 & Male & Mathematics & $11-20$ & High School & Undergraduate \\
\hline T19 & Female & English & $1-10$ & High School & Undergraduate \\
\hline $\mathbf{T 2 0}$ & Female & English & $1-10$ & High School & Undergraduate \\
\hline $\mathbf{T} 21$ & Male & Turkish Language & $11-20$ & Junior High & Undergraduate \\
\hline $\mathbf{T} 22$ & Male & Turkish Language & $11-20$ & Junior High & Undergraduate \\
\hline $\mathbf{T} 23$ & Male & Social Studies & $11-20$ & Junior High & Undergraduate \\
\hline T24 & Male & Religious Culture and Ethics & $1-10$ & Junior High & Undergraduate \\
\hline $\mathbf{T 2 5}$ & Female & Classroom Teacher & $21 \&$ over & Elementary & Undergraduate \\
\hline T26 & Male & Classroom Teacher & $11-20$ & Elementary & Undergraduate \\
\hline $\mathbf{T} 27$ & Male & Classroom Teacher & $21 \&$ over & Elementary & Undergraduate \\
\hline $\mathbf{T} 28$ & Female & Classroom Teacher & $1-10$ & Elementary & Undergraduate \\
\hline $\mathbf{T} 29$ & Female & Classroom Teacher & $11-20$ & Elementary & Undergraduate \\
\hline T30 & Male & Classroom Teacher & $21 \&$ over & Elementary & Undergraduate \\
\hline T31 & Male & Classroom Teacher & $21 \&$ over & Elementary & Undergraduate \\
\hline T32 & Male & Science and Technology & $21 \&$ over & Junior High & Undergraduate \\
\hline T33 & Male & Turkish Language & $11-20$ & Junior High & Undergraduate \\
\hline T34 & Female & English & $1-10$ & Junior High & Undergraduate \\
\hline T35 & Male & Classroom Teacher & $11-20$ & Elementary & Undergraduate \\
\hline T36 & Female & Physical Education & $11-20$ & High School & Undergraduate \\
\hline T37 & Male & Physical Education & $1-10$ & Junior High & Undergraduate \\
\hline T38 & Female & Technology and Design & $1-10$ & High School & Undergraduate \\
\hline T39 & Male & Mathematics & $11-20$ & Junior High & Undergraduate \\
\hline T40 & Male & Metal Technology & $21 \&$ over & High School & Undergraduate \\
\hline
\end{tabular}

2.1 Data Collection Instrument

A semi-structured interview form was used as data collection instrument in the study. Before the interview form was 
designed, a literature review was conducted on the topic of globalization and education was conducted and a two-part interview form was designed based on the interview questions found in studies by Balkar and Özgan (2010) and Gömleksiz and Kılınç (2012). The first section of the interview form included questions on participant demographics (gender, department, seniority, employment school type and education). The second part of the interview form included 5 questions that aimed to determine the participants' views on the impact of globalization on teaching profession. Expert opinion was obtained to determine whether the interview form was adequate to determine the views of teachers on the impact of globalization on teaching profession. As a result, the statement in 1 question was altered. Pilot interviews were held with 4 teachers. As a result of these interviews, it was determined that the questions on the interview form were clear and comprehensible. The following questions were included in the interview form:

1. How do you define the concept of global teacher?

2. What do you think about the changes that were implemented in Turkish teacher education system due to globalization?

3. What are your views on the positive and negative effects of globalization on teacher education process?

4. In your opinion, what are the changes that occurred in teacher roles due to globalization?

5. In your opinion, what are the changes that occurred in teacher qualificaions due to globalization?

\subsection{Data Collection and Analysis}

Data was collected with the interview form designed for the present study. One author visited the schools to interview the teachers, explained the objective of the study, and the volunteering teachers who considered that they could answer these questions after examining the questions on the interview form participated in the study. Some teachers did not volunteer to participate in the survey, stating that they would not be able to answer the questions. Since the teachers, who volunteered to participate in the study, wanted to fill in the interview forms at an appropriate time to provide comprehensive responses, the author waited up to 2 hours in certain schools to collect the final forms and in certain schools, the interview forms were left with the teachers and collected by the authors at a later date.

Descriptive and content analysis were conducted to analyze the study data. In the analysis of the data, initially, the answers provided by the participant teachers on the interview forms were coded based on the essence of their statements. Then, these codes were examined and similar codes were grouped under a common theme. The themes were created separately by the two researchers, and produced codes were compared and it was determined that the rate of agreement was $91 \%$. The participant responses on themes and codes that reflected disagreements were reviewed once more and a consensus was established between the researchers. Codes and themes were defined and tabulated in a comprehensible manner and the frequency of the statements related to each code and theme and information on the teachers who provided the statements were included in the table. The actual names of the participating teachers were replaced by the codes such as $\mathrm{T} 1, \mathrm{~T} 2, \ldots$

Each stage of the study was described in detail for reliability. To ensure the internal reliability of the study, the two researchers independently determined the data codes and the themes, and the agreement rate was determined with the comparison of these codes and themes. To ensure the internal validity of the study, an interview form was designed based on a literature review, teacher and expert opinions. To ensure the external validity of the study, the data were organized based on the determined codes and the themes and the data were meticulously presented to the reader without any interpretation. Thus, direct citations of participant statements were included in the manuscript. Furthermore, it was observed that study findings were consistent with the results in the literature. Thus, it could be stated that the study was valid and reliable based on the abovementioned findings. 


\section{Findings}

\subsection{The Concept of Global Teacher}

Findings obtained based on the views of teachers on the global teacher concept are presented in Figure 1.

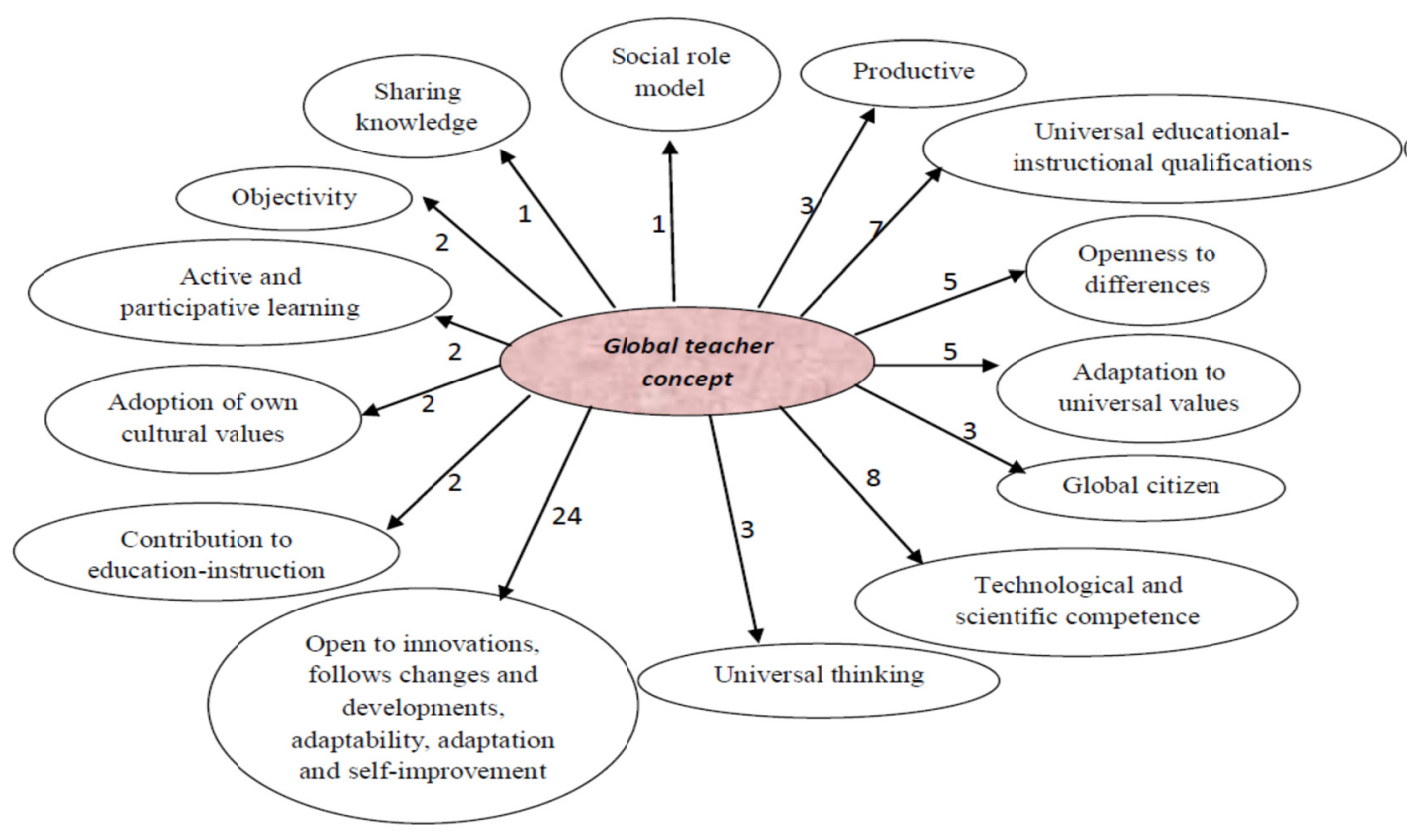

Figure 1. Teacher views on the concept of global teacher

Based on Figure 1, it was observed that the majority of the teachers defined the global teacher as teachers who are open to innovations, follow the changes and developments, adapt to and adopt these changes, and improve themselves. Furthermore, the global teacher was defined as a teacher who is competent in technology and information technologies, possesses universal educational-instructional qualities, is open to differences, is a global citizen, thinks universally, adapts to universal values, possesses the values of her or his own culture with an active and participatory learning approach, shares knowledge, is objective and a model for the society.

Participant teacher T1 defined global teacher as "These are teachers take into consideration the dynamics of modern education as well as our own educational dynamics. The global teacher is someone who follows scientific developments, social variables, educational perspectives, and their impact on individuals and adapts these to their educational-instructional practices." T29 defined it as "[teachers,] who follow the global education and pedagogy, methods and techniques and practice these in their classroom, teach universal values (such as peace, nature, humanity) to their students" and T37 stated that "The global teacher is the teacher who improves herself or himself based on the conditions of the time, keeps up with the technology, and advances education further."

\subsection{Assessment of the Changes Implemented in Turkish Teacher Education System within the Context of Globalization}

Findings obtained based on the views of teachers on the changes implemented in Turkish education system within the context of globalization are presented in Figure 2. 


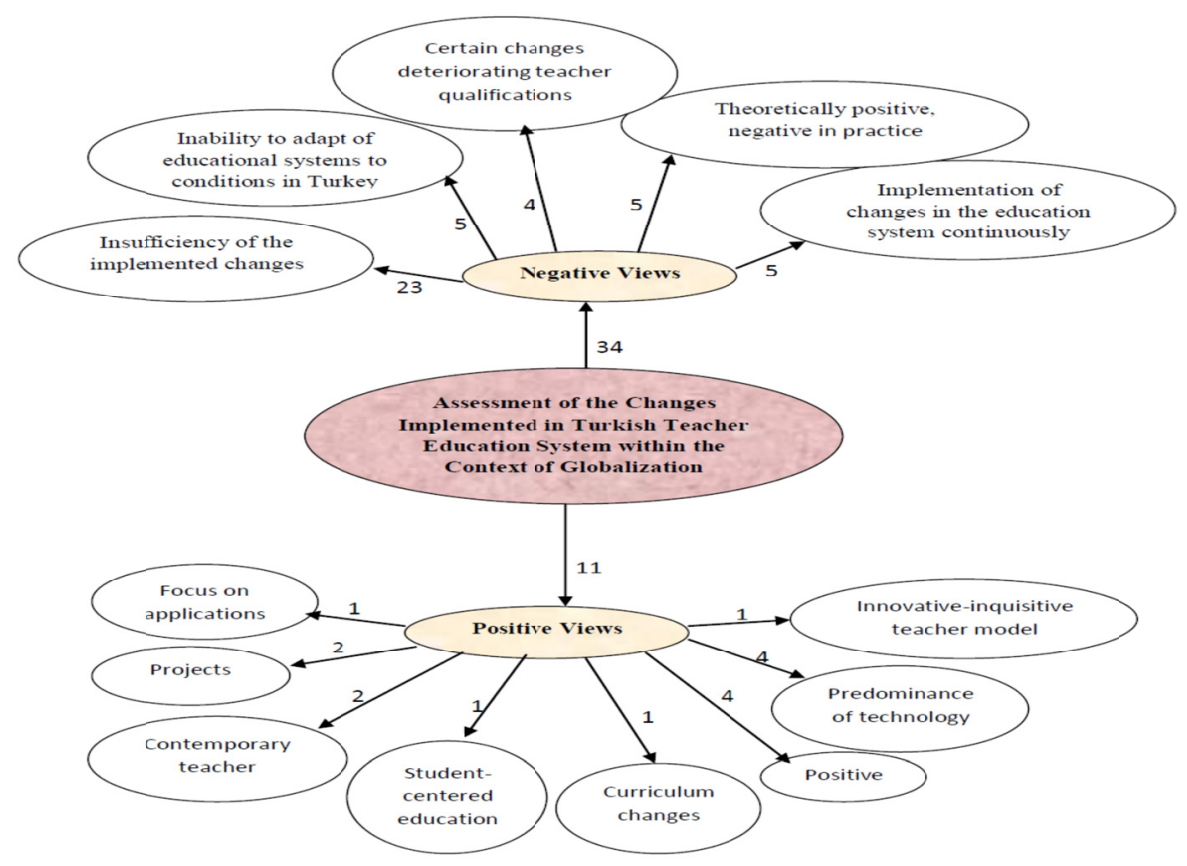

Figure 2. Teacher views on the changes implemented in Turkish education system within the context of globalization

Based on Figure 2, the views of teachers on the changes implemented in the teacher education system in Turkey as a result of globalization were grouped under 2 themes: Positive and Negative Views. Teachers mostly emphasized negative views. Teachers stated that the implemented changes were insufficient, the education systems in other countries were imitated without any adaptation to the conditions of Turkey, our education system changes constantly, and positive theoretical innovations were not transferred to practice, and even as a result of certain changes, the teacher qualifications were reduced. In addition to these negative opinions, certain teachers indicated that the implemented changes were positive, the technologies were prioritized, certain projects were conducted in the context of globalization, changes were implemented to train contemporary teachers, the changes aimed to train an innovative and inquisitive teacher model and various changes were implemented in the curriculum to emphasize practical applications and to stress the student-centered educational approach.

Participant teacher T2 stated that "I consider the changes made in the training programs positive. It prioritizes training of teachers who are innovative, inquisitive, and role models instead of rote learning." T4 said that "Significant steps are being taken to adapt to the globalization, but these are not enough. Interaction of pre-service teachers with teachers in other countries would contribute to these efforts. Certain projects are conducted in Turkey for this purpose, but they are not sufficient." T31 stated that "Since almost any activity in the context of globalization in our country is conducted for integration with the west, I consider these changes as insufficient and non-efficacious efforts. I consider that continuous changes based on new approaches everyday cannot provide the necessary productivity without the necessary infrastructure."

\subsection{The Impact of Globalization on the Process of Teacher Training}

Findings obtained based on the views of teachers on the impact of globalization on the teacher training process are presented in Figure 3. 


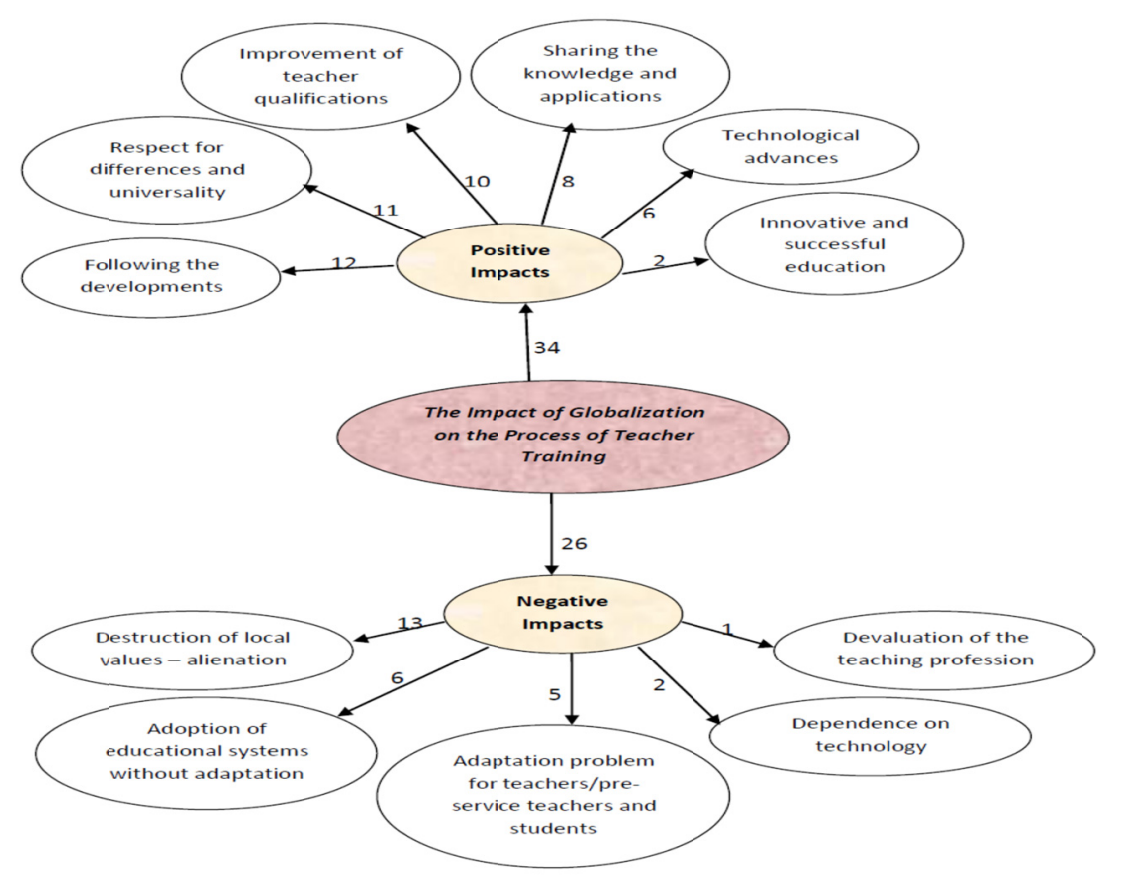

Figure 3. Teacher views on the impact of globalization on the teacher training process

As seen in Figure 3, teacher views on the effects of globalization on teacher training process were grouped under two themes; The Positive and Negative Impacts. The majority of the teachers stated that globalization positively affected the teacher training process. Teachers indicated that globalization made it possible to follow the developments in different countries, created respect for diversity, universality, improved the qualifications of teachers, enabled sharing of knowledge and practices, technological advancement, and innovative and successful education. However, they also stated that despite these positive impacts, globalization led to the destruction of the local values, alienation of teachers to their own values and culture, the adoption of education systems implemented in different countries without adaptation to the conditions in Turkey. And the teachers also emphasized that with globalization, teachers / pre-service teachers and students could experience adaptation problems to this process, the dependency to the technology increased and teaching profession was devalued as a result.

Participant teacher T23 stated that "I totally think that it is positive. Being aware of the educational systems that is adequate for the cultural structure in different countries, encountering different personality traits and determining the adequate education principles would widen the perspective and the horizon. As this would contribute to the personal development of the individual, the quality of the education would improve as a result." T29 stated both positive and negative impacts: "Of course we cannot alienate from the technology. As the world becomes a small village, we cannot ignore this fact. One of the positive effects is that we can instantly observe developments and innovations. Negative effects are corruption of national and moral values. But this is our choice."

\subsection{The Effect of Globalization on Teacher Roles}

Findings obtained based on the views of teachers on the impact of globalization on the teacher roles are presented in Figure 4. 


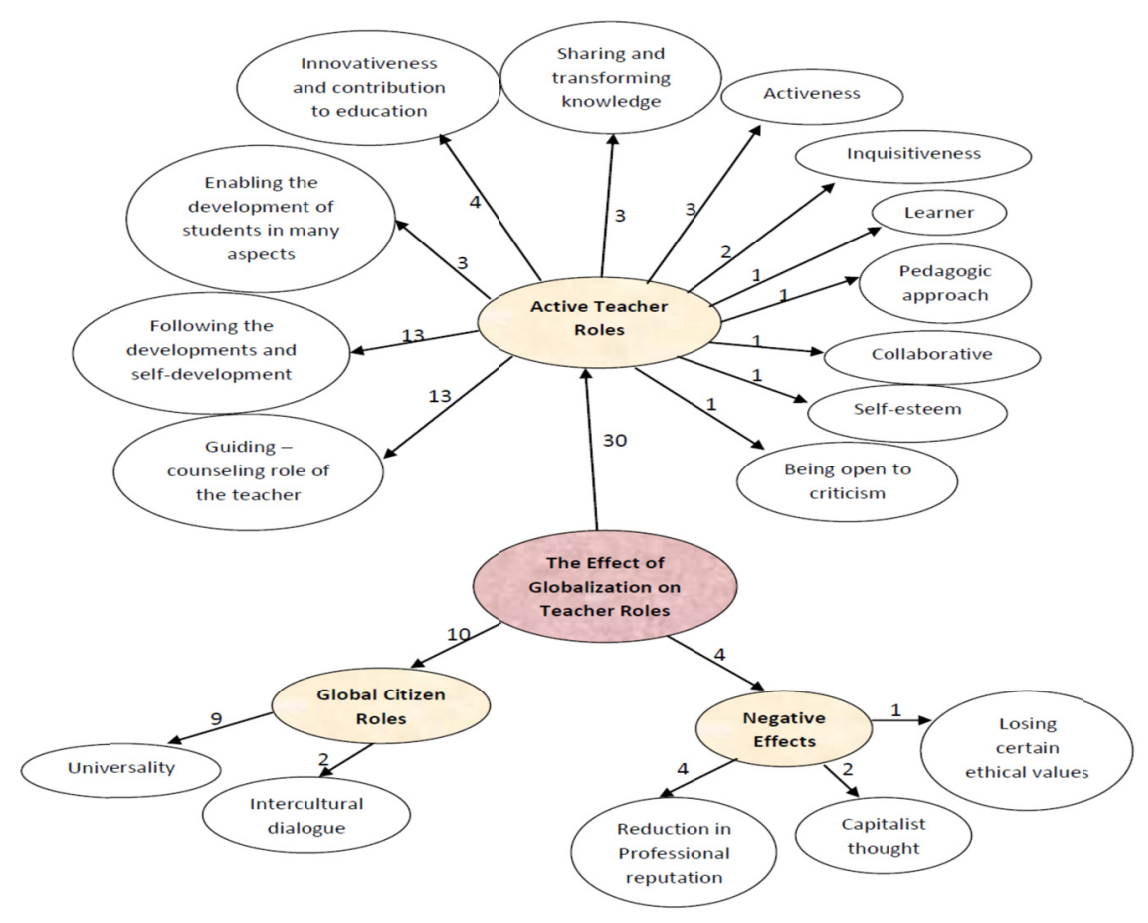

Figure 4. Teacher views on the impact of globalization on the teacher roles

Based on Figure 4, the teacher views on the impact of globalization on the role of teachers were grouped under three themes: The Active Teacher Roles, Global Citizen Roles and Negative Effects. The majority of teachers focused on the theme of active teacher roles. Most teachers emphasized that the changes were introduced to the roles of teachers with globalization and these differences emphasized the concept of student-centered education and the guide-counselor role of the teacher, and the requirement of following the developments and improving themselves based on these developments. Furthermore, the teachers also stated views on enabling the students to improve themselves in different aspects, innovation and its contribution to education, sharing and transforming knowledge, activeness, and the teacher roles in research, learning, pedagogical approach, collaboration, self-esteem, openness to criticism, universality and intercultural dialogue. It was also emphasized that the reputation of the teaching profession has diminished, teachers have started to act with a capitalist approach, and certain ethical values have disappeared due to globalism.

On global teacher roles, participating teacher T3 stated the following: "Teachers who are not open to knowledge and innovation and educators who cannot keep up with technological advances would experience serious problems and would not be able to address the needs of their students in this process. The teacher concept is evolving towards the type of teacher who shares knowledge and emphasizes collaborative workgroups. We have to be ready for rapid developments at the same pace." T6 stated that "I think the effectiveness of the teacher is diminishing. Now, information can be easily accessed without a need for the teacher. The teacher becomes a guide, not the instructor. Teacher instructs the method of acquiring knowledge rather than instructing the knowledge. This leads to the fact that teachers are no longer role models for the student. Now the role model is the virtual world, not the teacher who lives, have contact with the students." T35 stated the following: "Good examples, practical examples broaden the teacher's horizon. The educators, who are aware of the fact that they are in the same boat, in a way, accept the responsibility for the future. We all need the world. I think the process raise our awareness on that fact." T31 stated the following: "Teaching, which was the profession of love and sacrifice, was replaced with capitalist approach and started to ask for more. Certain ethical values began to gradually disappear with self-esteem, individualization, and meta-emotions. Idioms such as you get what you pay for became common in education. The reputation of reaching has diminished, it could soon disappear completely."

\subsection{The Impact of Globalization on Teacher Qualifications}

Findings obtained based on the views of teachers on the impact of globalization on teacher qualifications are presented in Figure 5. 


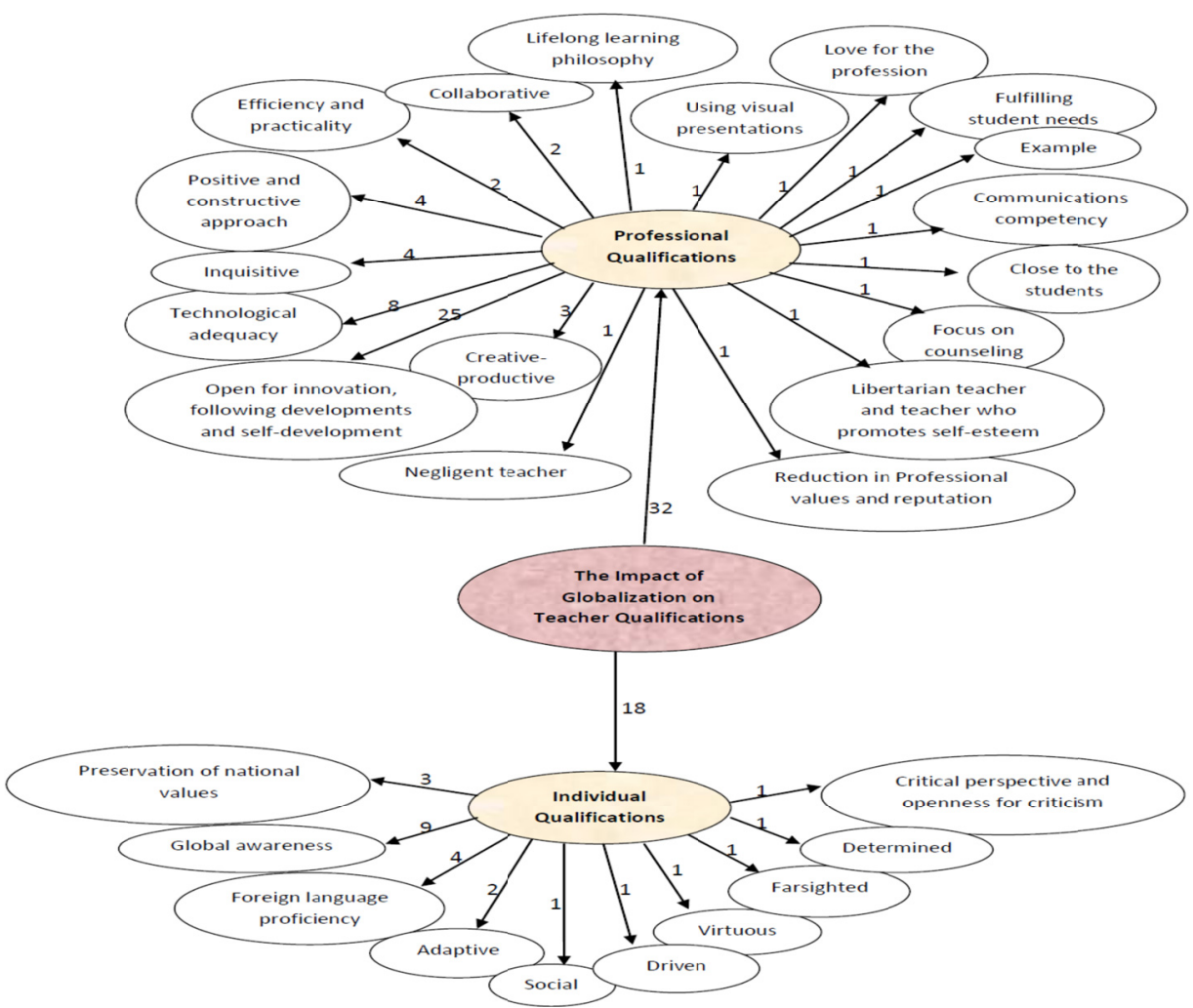

Figure 5. Teacher views on the impact of globalization on teacher qualifications

Based on Figure 5, the teacher views on the impact of globalization on teacher qualifications were grouped under two themes: Professional and Individual Qualifications. The majority of teachers expressed opinions on the theme of professional qualifications. Teachers expressed that teachers should be open to innovations, especially in their profession, improve themselves by monitoring the changes, possess technological competence, be researchers, have a positive and constructive approach, be creative-productive, efficient and practical, collaborative, maintain a continuous learning philosophy, love their profession, utilize visual presentations in class, respond to student needs, provide a role model, possess communicative competence, be close to students, provide guidance, offer opportunities for students to experience their freedoms and develop their self-esteem as a result of globalization. In contrast, they identified that globalization led to a decrease in professional values and dignity of the teachers, and the teachers might behave as indifferent teachers to various events and demonstrate interest only in their job. On the other hand, they stated that teachers should possess global awareness, be fluent in foreign languages, protect their national values, have a critical point of view and a critical approach, have a adaptive, virtuous, social, driven, farsighted and determined personality.

Participant T6 stressed both professional and individual qualifications by listing "the requirements of a foreign language, to become fluent in foreign languages, to use technology effectively, to broaden one's horizon, and to follow global developments", while T14 stated that "teachers need to improve themselves. They realize that they should use computers and the internet actively and utilize the other means of communication well. Teachers should follow the changes in these fields and get the necessary training and take advantage of the training in their classes." T28 stated the following: "They should be inquisitive, engage in self-development and follow the innovations". According to T31, "Being a teacher is the capacity to give without taking. Teacher is an individual who is fair, trustworthy, would not breach one's trust, thankful and one who teaches. Most of these values are lost. Professional respect is tainted with individual egos. This helped to reduce the respectability of the profession in society. Material life became prominent. Professional values are eroded." T40 emphasized professional qualifications and stated that "Since the concept of globalization has emerged, it has been suggested that teachers should give their students the opportunity to live as freely as possible and to mobilize all opportunities for the development of their self-esteem. Teachers have been asked to teach how to access information rather than providing the information directly."

\section{Discussion}

With the impact of globalization, changes in the roles of teachers and students in educational systems were experienced 
and a process of change from the industrial society to the information society was observed (Chinnammai, 2005). As a result, the concept of conventional teacher was transformed into the concept of the global teacher. It was determined in the study that the roles of teachers differentiated as a result of globalization. In the study, it was determined that globalization had negative effects besides several positive effects on teachers' qualifications. Similar roles and qualities are emphasized in the literature. For example, in a study conducted by Balkar and Özgan (2010), teachers stated that their tasks were altered by the influence of globalization, they were not knowledge transmitters and emphasized their roles of training the students to acquire critical thinking skills and promoting their social development. In a study by Guo (2014: 3-4), certain skills required for the teachers to have global competency were determined as follows: to possess pedagogical skills to assist students to analyze and assess multicultural traditions and multidisciplinary perspectives, possess intercultural competence and the ability to adapt to cultural norms and social diversity, help students become responsible global citizens, possess the knowledge that global events and problems are interdependent and an awareness of social problems, pay attention to other individuals, to understand the nature of global economic integration and the mutual dependence and interdependence of peoples, to respect and protect cultural diversity, to fight for social justice for all people and to protect the universe.

According to Cates, one of the most important tasks of teachers in the global age is to help students learn about the differences among people in the multicultural world and the significant global problems they face. Cates stressed that English is an international language used by people around the world to communicate with each other and especially emphasized the significance of English teachers in performing this task and stated that they have the responsibility to reach fluent English and to help students become global citizens responsible for a better world. Furthermore, Cates stated that the classroom environment should promote international awareness and curiosity and interest about the multicultural world and teachers should integrate global themes in their teaching methodology and provide experiential opportunities for educational activities such as games, role-playing and videos that are designed in global themes. At the same time, it was stated that teachers should prepare a slide introducing their trips to foreign countries and share them with their students, and should not miss the opportunities to participate in various projects and international trips. It was emphasized that teachers should engage in charity activities such as setting up a global issues workgroup, finding English pen pals from foreign countries for their students and helping people in different countries, and organizing extracurricular activities that can increase global awareness. It was also suggested that teachers should explore global education and related fields, participate in a special interest group on a global topic, and in various educational courses on global education to improve professional development (Cates, 2004).

According to Güven (1999: 150), teachers should prepare students for the conditions required by the global age. For this purpose, teachers should initially improve themselves, and acquire the competencies of teamwork and to enable the students to acquire the desired behavior due to the occurring changes and developments. Furthermore, teachers should know that there is a specific place and time for learning, should train the students as such, and should teach the students to work and live together to learn. There is a need for teachers who are able to comprehend the structure and vital patterns of the global information society and the paradigms of the educational system in the age of globalism, educate students as active, knowledgeable and productive individuals not passive information consumers, follow up and coordinate the use of information technologies (Aslan, 2004). Teachers should be individuals who possess the competence to use educational technologies in the global age, could learn and aim to develop high level thinking and synthesis skills in student, not the development of skills (Genç, 2000).

Salandanan et al. (2006) suggested that the global teacher should have five basic roles. The first is the effective teacher, who considers teaching as a continuous learning. The second is the facilitator teacher who facilitates learning, provides various educational opportunities and the choice of educational alternatives for the students. The third is the researcher teacher who undertakes a formal or informal research to collect data / information and to offer development suggestions. The fourth is the ethical teacher who possesses a system of moral values that could have a positive impact on students. The fifth is the psychological teacher who is a social model, evaluator, researcher, a human encyclopedia, spiritual supporter, parental associate, friend and a group leader (Cited by Enanoza \& Abao, 2014: 357-358).

Present study findings demonstrate that globalization altered the roles of the teachers and some of the roles were lost, while others eroded or became symbolic. Because, the in-classroom roles of the teacher are listed as providing information, to discipline and judge, being a confidant, parenting, socialization, methodologist, leadership, giving advice, while the peripheral roles of the teacher are described as assisting the environmental development, being a social leader, an advocate of middle class morality, cultured individual, leader of new ideas, child education specialist and idealist. On the other hand, there is a transformation from a modernist teacher-centered teaching to a postmodern student-centered learning. With a neoliberal perspective, the individual is considered at the center, the social control mechanisms are weakened and individual differences are emphasized. The teacher-centered approach to education includes the teacher roles of being a role model and representing local values, thus it is positioned as if it was against 
the student and excluded with the excuse that it is unsuitable for neoliberal lifestyle and educational philosophy and considered outdated (Cantekin, 2015: 50-51).

In the present study, it was emphasized that globalization led to a decrease in the professional values and reputation of the teachers, that the teachers could become disinterested in other affairs and only concentrate on teaching and act with capitalist ideas. As a result of globalization, material gains are prioritized and protection of cultures is ignored (Chinnammai, 2005). However, Kant's "world citizen" was an ethical individual. Globalization primarily emphasized the economy and economic globalization led to cultural globalization, which in turn trivialized other essential values (i.e., law, identity, ethics), thus increasing the problems (Takış, 2002). The fact that globalization, under the influence of neoliberal policies, trained individuals who live in the moment and ignore the past or the future, prioritize personal interests and ignores social interests, and acts with an economic priority, led to a change in the objectives of educational institutions. Furthermore, several previous studies emphasized that globalization altered the functions of schools, serving the capitalism. Based on this assumption, globalization expects the schools to train "producer and consumer individual in the market" and schools are considered useful when they educate individuals for this purpose (Uslu Çetin, 2015: 5-6). Therefore, it can be argued that the teachers are also directed to exhibit behavior that are in line with the abovementioned approach.

Based on the study findings, it can be stated that the changes implemented in the teacher education system in Turkey do not constitute and adequate response to globalization. It is then necessary to restructure the teacher training system in Turkey with a global perspective. On this issue, Bruce et al. (1991) stated that faculty members need to address three strategic issues to develop a global perspective in teacher training curriculum. The first issue is to determine the objectives and scope of the program, which would be designed to emphasize a global perspective. The second is to determine the compelling reasons for developing a specific global perspective. The third is to decide whether to integrate global education into the teacher education curriculum, or whether to create a new course or courses for this purpose. Another method is the inclusion of global goals by the faculty members in their courses. It was emphasized, however, that integration of the global perspective in the curriculum rather than the courses would be more difficult, but more effective. On the other hand, personal intercultural experiences simulated both at home and abroad are an important part of global and international education. Participating in educational activities with students in other countries with different cultures, working with international students, spending academic years abroad, student and academician exchange programs and business trips are methods to enable teachers to acquire intercultural knowledge, improve their intercultural communications skills and to motivate teachers to teach with a global perspective (Gilliom, 1993; Wilson, 1982, cited by Merryfield, 1995: 3).

In the present study, it was observed that globalization had mostly positive effects on the teacher training process, however it was determined that there were certain adverse effects as well as these positive effects. Similar impacts are stressed in the literature. In a study conducted by Balkar and Özgan (2010), the teachers expressed their concerns about the loss in the significance of Turkish language and Turkish values with globalization. And in the study conducted by Gömleksiz and Kılınç (2012), on the effects of globalization on Turkish education system, faculty members stated that globalization positively enabled the comparison of the education programs with international programs, easy access to information and training versatile individuals, promoted new quests and increased living standards, however also led to alienation and imitation of foreign curricula as well. According to Erdem (2008), the number of educational science faculties increased with globalization, educational sciences departments were restructured and accredited, the number of graduate students in educational science departments abroad increased significantly, online educational science journals were published, access to online educational manuscripts was facilitated and Turkey began to participate effectively in several international projects on professional development. Especially the number of classrooms and publications designed specifically for the PPSE increased and educational science findings became a commodity. Furthermore, due to globalization, there is an increase in the number of private and foundation universities and a decline in the quality of education and the students in higher education. The students with low academic achievements and high financial means started to attend private or foundation universities and academic achievement and financial power were equalized (Uslu Çetin, 2015: 6). Thus, the gap between the educational opportunities for the rich and the poor was widened. In fact, at the center of the debate on globalization, there is the inequality-based theories and practices of the neoliberal thought that is the owner of the globalization process (Cinar, 2009: 16).

Today, globalization is considered as a method where the applications produced by Western countries based on their own specifications are copied and implemented or enforced out of their original context. From this point of view, globalization is a process that can be quite damaging to the local, and even to certain cultural forms. In fact, when an individual with a certain culture is educated in an education system copied from a different culture, the individual is alienated from her or his own culture and values, and the individual ends up despising the lifestyle of her or his society (Cantekin, 2015). Therefore, it is necessary to blend and synchronize the local and global to achieve a global 
perspective on the teacher training process and to preserve national and spiritual values and culture by considering both the inevitability and the positive and negative effects of globalization. In other words, it is necessary to equip teachers with the characteristics of their culture, while training the teachers with the qualifications and competencies required by globalization. Because, globalization is a complex phenomenon that aims the integration of different societies based on common ground and cultural pluralism, but it does not aim the nations to lose their characteristics (Güven, 1999). Teachers, who are required to live in the global age, should be global citizens with global vision, ideas and knowledge, while retaining the nutrition provided by their own culture and in return, enrich their culture (Drucker, 1993: 70). Thus, it is necessary to develop a teacher training system and a teacher profile, which cannot be affected by the negative aspects of globalization and can reconcile national values with global values (Aslan, 2004: 4). Because, while educational institutions aim at transferring cultural heritage from one generation to another, these should also help individuals to easily adapt to global and local events and changes and developments in fields such as science, technology, economy, sports, arts, literature, etc. (Özdemir, 2011: 94) Thus, it is the duty of the teachers to protect the identity of their society and to prepare the individuals for the conditions of the globalization (Güven, 1999).

\section{Conclusion}

In the present study, based on the views of teachers, the global teacher could be defined as a global citizen and a universal teacher who possesses the qualifications and competencies required by globalization, knows about global changes and developments and improves herself or himself accordingly. In a more detailed definition, global teacher could be defined as a teacher who is open for innovations, follows changes and developments, adapts to these changes and developments, adopts these changes and developments, and improves herself or himself based on these developments, has technological and computational competence, possesses universal education-instruction qualifications, is open to differences, is a global citizen with universal thinking, adapts to universal values, adopts the values of her or his own culture, is productive, contributes to education-instruction, possesses active and participative learning approach, shares knowledge, is objective and a role model for the society.

It was determined in the study that the roles of teachers differentiated as a result of globalization. Based on these differences, it can be argued that student centered education approach can be emphasized and teachers should fulfill the new roles of a guide-counselor, of those who follow the developments and improve themselves accordingly, enable the students to improve themselves in different aspects, contribute to innovativeness and education, share and transform knowledge, be collaborative, self-confident, open to criticism and universalist and establish an intercultural dialogue.

As a result of the study, it is observed that globalization caused differences in qualifications of the teachers and thus, teachers should be open to innovations in their profession, to improve themselves by adopting the changes, to possess technological competency, to be inquisitive, creative-productive and practical, collaborative, have a positive and constructive approach, adopt lifelong learning philosophy, love the profession, utilize visual presentations in the classroom, be responsive to student needs and a role model, competent in communications, close to students, prioritize counseling, offer opportunities for students to experience their freedom and improve their self-esteem. On the other hand, it can be argued that they should possess a global awareness, be fluent in foreign languages, protect their national values, have a critical approach, be open for criticism, have an adaptive, virtuous, social, driven, farsighted and determined personality.

The changes in the definition, roles and qualifications of teaching introduced with globalization necessitated certain changes in teacher education system and various reforms were introduced in the teacher education system in Turkey. Assessment of the teacher views on the evaluation of these changes within the context of globalization demonstrated that certain changes were positive, the technology was emphasized, certain projects were conducted within the context of globalization, certain changes were implemented to train the type teachers required by the times and it was aimed to train innovative researcher teacher model, and consequently, certain changes were implemented in the curricula, applications and student-centered education were emphasized and it was observed that the implemented changes were often inadequate, the educational systems of other countries were implemented directly without adaptation to the local conditions, the education system has been constantly changing, although positive changes were implemented in theory, these changes were not practiced, and even certain changes led to a decrease in the quality of teachers.

Globalization affects the teacher training process both positively and negatively, similar to its impact on other fields. Based on the present study findings, the majority of the teachers stated that globalization positively affected the teacher training process. According to teachers, the positive effects could be listed as follows: globalization allows for the follow-up of developments in different countries, respect for differences, universality, globalization increased teacher qualifications, sharing of information and applications, technological advances, and resulted in an innovative and successful education. However, in addition to the abovementioned positive effects, teachers stated that it destroyed local values, alienated the teachers from their own values and culture, the education systems applied in different countries 
were adopted without adaptation, caused the possibility of adaptation problems that could be experienced by teachers / pre-service teachers and students alike, increased dependence on technologies and reduced the value of the teaching profession.

\section{Recommendations}

Based on the findings of the present study and the requirement to equip teachers with global competencies, it can be recommended that teachers should follow up global educational and technological changes and adapt to the pace of these changes, adopt these changes in educational activities and improve themselves by participating in various vocational courses. Teachers can conduct national and international projects. They can improve their ability to utilize technological tools actively. They can enable the adoption of national and universal values by their students by preserving their national values and embracing the universal values. They can learn English, which is an international language, at a proficient level and participate in language courses to improve their ability to speak different languages. By integrating global themes into teaching-instruction activities, they can improve the students' awareness about global events, while providing the real achievements of the course.

For pre-service teachers to acquire global competencies, Turkish teacher training system should be reconstructed by adapting global teacher training system after a comprehensive analysis based on the conditions in Turkey and the Turkish culture and infrastructure work are completed and the pre-service teachers should be educated in application-oriented new generation faculties of education. Training opportunities should be provided in countries with developed education systems for each pre-service teacher and teaching practice courses could be conducted in a domestic school in one semester and in a foreign school in the second semester on senior year. Thus, both the awareness of pre-service teachers about global education could be raised and their alienation from their own culture could be prevented. To improve the global awareness of pre-service teachers, a course on global problems and events could be designated as a compulsory course. Student clubs could be organized in faculties of education to promote global awareness. The fundamental achievements that are specified in teacher training curriculum could be integrated with global topics.

For future studies, the following can be recommended: A scale for global teacher qualifications and roles can be developed to determine teachers' fulfillment levels in global teacher roles. The correlations between global teacher roles and qualifications and student achievements and teacher values can be investigated. Qualitative research can be conducted to investigate the impact of globalization on the administrator-student-parent profile in detail.

\section{References}

Akçay, R. C. (2003). Globalization, educational deprivation and adult education. Milli Eğitim Dergisi, 159.

Akdemir, A. S. (2013). A history of teacher training programmes and their problems in Turkey. Turkish Studies International Periodical For The Languages, Literature and History of Turkish or Turkic, 8(12), 15-28.

Al-Rodhan, N. R. F., \& Stoudmann, A. G. (2006). Definitions of globalization: A comprehensive overview and a proposed definition. Program on the Geopolitical Implications of Globalization and Transnational Security. Retrieved from http://citeseerx.ist.psu.edu/viewdoc/download?doi=10.1.1.472.4772\& rep=rep1\&type=pdf

Apple, M. W. (2011). Global crises, social justice, and teacher education. Journal of Teacher Education, 62(2), 222-234. https://doi.org/10.1177/0022487110385428

Aslan, K. (2004). Educational perspectives in globalization. Ege Eğitim Dergisi, 5, 1-5.

Aydın, A. (1998). Restructuring of education faculties and problem of teacher training. Kuram ve Uygulamada Eğitim Yönetimi, 4(15), 275-286.

Balay, R. (2004). Globalization, information society and education. Ankara Üniversitesi Eğitim Bilimleri Fakültesi Dergisi, $3(2), 61-82$.

Balc1, A. (2006). Roland Robertson, globalization and culture. Bilgi, 12(1), 25-36

Balkar, B., \& Özgan, H. (2010). Teachers' opinions on the effects of globalization on the education process in primary education. Mehmet Akif Ersoy Üniversitesi Eğitim Fakültesi Dergisi, 19, 1-22.

Bolat, Y., \& Çelik, A. (2014). Effects of globalization on the Turkish education system and reflections in primary school teacher program. Route Educational and Social Science Journal, 1(3), 158-175. https://doi.org/10.17121/ressjournal.80

Bruce, M. G., Podemski, R. S., \& Anderson, C. M. (1991). Developing a global perspective: Strategies for teacher education programs. Journal of Teacher Education, 42(1), 21-27. https://doi.org/10.1177/002248719104200104

Çalık, T., \& Sezgin, F. (2005). Globalization, information society and education. Kastamonu Eğitim Dergisi, 13(1), 55-66. 
Cantekin, Ö. F. (2015). Globalization and education: Transformation of the "Homo Economicus" model in education. Akademik hassasiyetler, 2(4), 43-72.

Cates, K. (2004). Becoming a global teacher: Ten steps to an international classroom. Publications of the Japan Association for Language Teaching. Retrieved from

http://jalt-publications.org/ttl/articles/694-becoming-global-teacher-ten-steps-international-classroom

Cerit, Y. (2004). The educational effects of globalization. Abant İzzet Baysal Üniversitesi Sosyal Bilimler Enstitüsü Dergisi, 2(9), 47-65.

Chinnammai, S. (2005). Effects of globalisation on education and culture. Paper presented at ICDE International Conference, 19-23 November, New Delhi.

Çınar, İ. (2009). Globalization, education and future. Kuramsal Eğitimbilim, 2(1), 14-30.

Dağlı, A. (2007). Globalization towards Turkish Education System. Dicle Üniversitesi Ziya Gökalp Ë̆itim Fakültesi Dergisi, 9, 1-13.

Drucker, P. F. (1993). The rise of the knowledge society. Wilson Quarterly Spring, 17(2), 52-71.

Easterly, J. L. (1994). Promoting global teacher education: Seven reports. Retrieved from http://files.eric.ed.gov/fulltext/ED368704.pdf

Elçin, A. B. (2012). History of globalization. Retrieved from http://www.meritymm.com/wp-content/uploads/2013/05/kuresellesme.pdf

Enanoza, F. L., \& Abao, E. L. (2014). Roles and performance expectancies of a global teacher. European Scientific Journal, 10(1), 356-373.

Erdem, A. R. (2008). Today and future of educational sciences in Turkey in terms of globalization. Bilim, Eğitim ve Düşünce Dergisi, 8(4).

Erkızan, H. N. (2002). On the historical and intellectual foundations of globalization. Doğu Batı Dergisi, 5(18), 65-79.

Genç, S. Z. (2000). Teacher education in information society. Kuram ve Uygulamada Eğitim Yönetimi Dergisi, 6(3), 375-386.

Giddens, A. (2000). Run away world. (O. Akınhay Çev.). İstanbul: Alfa.

Gömleksiz, M. N., \& Kılınç, H. H. (2012). Views of academicians on the effect of globalization on curriculum: A qualitative study. Mustafa Kemal Üniversitesi Sosyal Bilimler Enstitüsü Dergisi, 9(17), 397-413.

Gümüş, O. (2013). Social state against globalization. (pp 325-329). Paper presented at V. International Symposium on Social Rights (31 October-1 November 2013). Retrieved from http://www.sosyalhaklar.net/2013/bildiriler/gumus.pdf

Guo, L. (2014). Preparing teachers to educate for 21st century global citizenship: Envisioning and enacting. Journal of Global Citizenship \& Equity Education, 4(1), 1-23.

Güven, İ. (1999). Globalization and its reflections on educational system. Ankara Üniversitesi Eğitim Bilimleri Fakültesi Dergisi, 32(1), 145-159. https://doi.org/10.1501/Egifak_0000000017

İlhan, H. İ. (2009). Reflections on globalization education. (Unpublished master's thesis). Gazi University Educational Sciences Institute, Ankara.

Karaman, K. (2010). Globalization and education. Journal of World of Turks, 2(3), 131-144.

Kozanoğlu, H. (2002). Globalization and supranational capital class. Doğu Batı Dergisi, 5(18), 55-64.

Maguire, M. (2010). Towards a sociology of the global teacher. In Apple, M. W., Ball, S. J. \& Gandin, L. A. (Eds.), The Routledge international handbook of the sociology of education. (pp. 58-68). London and Newyork: Routledge Taylor \& Francis Group.

Mc Fadden, J., Merryfield, M. M., \& Barron, K. R. (1997). Multicultural \& global/international education: Guidelines for programs in teacher education. Retrieved from http://files.eric.ed.gov/ fulltext/ED405301.pdf

Merryfield, M. (1994). Teacher education in global \& international education. ERIC. Retrieved from http://files.eric.ed.gov/fulltext/ED376166.pdf

Merryfield, M. (1995). Teacher education in global and international education. ERIC Digest. Retrieved from http://files.eric.ed.gov/fulltext/ED384601.pdf

Merryfield, M. M. (1996). Making Connections between Multicultural and Global Education: Teacher Educators and Teacher Education Programs. AACTE Publications, One Dupont Circle, Suite 610, Washington, DC 20036-1186. 
Retrieved from http://files.eric.ed.gov/fulltext/ED394968.pdf

Öz Kılınç, M. (2009). The effects of globalization process on the education and teacher's identity. (Unpublished doctoral thesis), Ege University Social Sciences Institute, İzmir.

Özdemir, S. M. (2011). Education and curricula within the context of social change and globalization: A conceptual analysis. Ahi Evran Üniversitesi Eğitim Fakültesi Dergisi, 12(1), 85-110.

Pinnock, H., \& Nicholls, H. (2012). Global teacher training and inclusion survey: Report for UNICEF rights, education and protection project (REAP) Retrieved from

http://worldofinclusion.com/v3/wp-content/uploads/2014/01/Annex-v_Final.pdf

Rathi, K. N., \& Ramachandran, R. (2012). Developing global teacher. Journal of Current Trends in Education and Research, 3 (2), 14-17.

Reimer, K., \& McLean, L. R. (2009). Conceptual clarity and connections: Global education and teacher candidates. Canadian Journal of Education, 32(4), 903-926.

Şahin, S. (2004). Globalization, the European Union and education. Dokuz Eylül Üniversitesi Buca Eğitim Fakültesi Dergisi, 16, 38-44.

Schwille, J., Dembélé, M., \& Schubert, J. (2007). Global perspectives on teacher learning: Improving policy and practice. International Institute for Educational Planning (IIEP) UNESCO.

Takış, T. (2002). A fantastic festival: Globalization. Doğu Batı Dergisi, 5(18).

Talas, M. (2016). The phenomenon of globalization. İn M. Talas \& S. S. Bildirici (Eds.). Globalization with opportunities and threats. (pp. 9-18). Ankara: Edge Akademi.

Tarman, B. (2010). Global perspectives and challenges on teacher education in Turkey. International Journal of Arts \& Sciences (IJAS), 3(17), 78-96.

Tatto, M. T. (2006). Education reform and the global regulation of teachers' education, development and work: A cross-cultural analysis. International Journal of Educational Research, 45(4), 231-241. https://doi.org/10.1016/j.ijer.2007.02.003

Torney-Purta, J. (1982). The global awareness survey: Implications for teacher education. Theory into Practice, 21(3), 200-205. https://doi.org/10.1080/00405848209543006

Trisler, C. E. (1993). Global issues and environmental education. ERIC/CSMEE Digest. (pp. 1-8). Retrieved from http://files.eric.ed.gov/fulltext/ED359051.pdf

Uslu, Ç. O. (2015). Impacts of globalization on various aspects of education. Çağdaş Yönetim Bilimleri Dergisi, 1(1), 19.

Üstüner, M. (2004). Teacher training in the Turkish education system and the problems of today from the past to the present day. İnönü Üniversitesi Ë̆itim Fakültesi Dergisi, 5(7), 63-82.

West, C. (2013). Global classrooms, global teachers: Building cross-cultural competence through experiences abroad. Retrieved from https://www.nafsa.org/uploadedFiles/Chez_NAFSA/Find_Resources/Publications/Periodicals/Epublications/Globally \%20Classrooms\%20Global\%20Teachers.pdf

Yıldırım, A., \& Şimşek, H. (2011). Qualitative research methods in the social sciences. Ankara: Seçkin.

YÖK (2007). Explanation about new programs to be implemented in training faculties. Retrieved from http://www.yok.gov.tr/documents/10279/49665/aciklama_programlar/aa7bd091-9328-4df7-aafa-2b99edb6872f

YÖK (2016). The education faculties are being restructured, and the practice of "restricting the order of succession" comes in the next period. Retrieved from

http://yok.gov.tr/web/guest/\%20icerik/-/journal_content/56_INSTANCE_rEHF8BIsfYRx/10279/\%2027747321

Yurdabakan, İ. (2002). Approaches about globalization and education. Eurasian Journal of Educational Research, 6, 61-66.

\section{Copyrights}

Copyright for this article is retained by the author(s), with first publication rights granted to the journal.

This is an open-access article distributed under the terms and conditions of the Creative Commons Attribution license which permits unrestricted use, distribution, and reproduction in any medium, provided the original work is properly cited. 